\title{
Acute parvovirus B19 infection diagnosed by bone marrow biopsy
}

\author{
Sukesh Manthri, Kanishka Chakraborty
}

Department of Internal

Medicine, Division of

Hematology/Medical Oncology, East Tennessee State University, Johnson City, Tennessee, USA

\section{Correspondence to}

Dr Kanishka Chakraborty, chakrabk@etsu.edu

Accepted 13 April 2019

\section{DESCRIPTION}

A 57-year-old woman with a history of multiple sclerosis on glatiramer acetate presented with atypical chest pain and was noted to have worsening pancytopenia (haemoglobin $108 \mathrm{~g} / \mathrm{L}$, white blood cell (WBC) $1.0 \times 10^{9} / \mathrm{L}$, platelets $\left.58 \times 10^{9} / \mathrm{L}\right)$. Cardiac workup including cardiac catheterisation was unremarkable. She had chronic pancytopenia (baseline haemoglobin $116 \mathrm{~g} / \mathrm{L}$, WBC $2.3 \times 10^{9} / \mathrm{L}$, platelets $81 \times 10^{9} / \mathrm{L}$ ) identified over 10 years ago with previous workup negative for primary haematological disorder, felt to be secondary to malabsorption related to gastric bypass along with bone marrow (BM) suppression due to glatiramer. Reticulocyte count was 0.3 (normal $0.5 \%-2.5 \%$ ). It was inappropriately low to the degree of anaemia suggesting BM suppression. Peripheral smear exam did not show any findings suggestive of haemolysis. Given worsening pancytopenias, a BM examination was done. The BM demonstrated hypercellularity (50\%) with decreased erythroid lineage and markedly enlarged erythroblasts, with virus inclusions (figure 1). Immunostain for capsid protein of human parvovirus B19 was positive (figure 2). Antiparvovirus B19 IgM and IgG were positive (11.89 and 3.39; positive index 1.11) by enzyme immunoassay, and qualitative PCR detected DNA for parvovirus B19. Seroconversion was seen 8 weeks later with antiparvovirus B19 IgM and IgG were 1.18 and 5.66, respectively. Parvovirus B19 is a small single-stranded DNA virus and selectively replicates in erythroid precursors in BM or peripheral blood causing transient or permanent suppression of erythropoiesis. ${ }^{1}$ These patients will develop chronic anaemia, pure red cell aplasia or, less often, leucopenia and thrombocytopenia. Although the classic BM findings have been described, they can easily

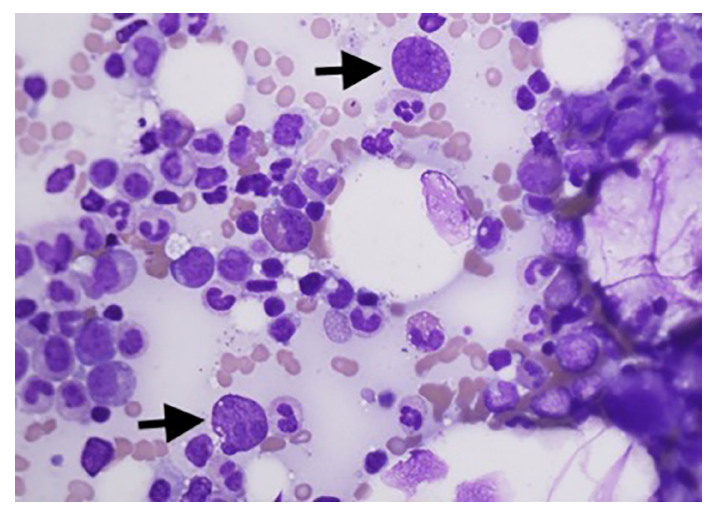

Figure 1 Bone marrow aspirate showing parvovirus B19 infecting erythroid precursors.

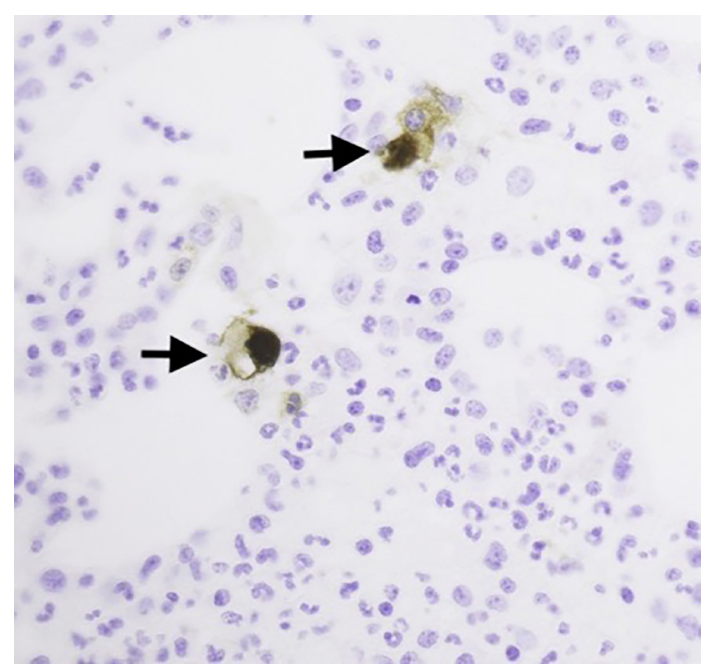

Figure 2 Immunostain highlights the capsid protein of human parvovirus B19 in the erythroid precursors.

\section{Learning points}

- Parvovirus B19 is a rare but known cause of pancytopenia. It is usually seen in immunocompromised patients.

- Anecdotal data from rare case reports have shown some benefit by treating with intravenous immunoglobulin infusions.

be overlooked, leading to delayed therapy. ${ }^{2}$ Our patient's pancytopenia gradually improved to baseline with intravenous immunoglobulin infusions.

Contributors SM worked on brief case description. KC supervised and edited the final abstract.

Funding The authors have not declared a specific grant for this research from any funding agency in the public, commercial or not-for-profit sectors.

Competing interests None declared.

Patient consent for publication Obtained.

Provenance and peer review Not commissioned; externally peer reviewed.

\section{REFERENCES}

1 Pascutti MF, Erkelens MN, Nolte MA. Impact of viral infections on hematopoiesis: from beneficial to detrimental effects on bone marrow output. Front Immunol 2016;7:364.

2 Rajput R, Sehgal A, Jain D, et al. Acute parvovirus B19 infection leading to severe aplastic anemia in a previously healthy adult female. Indian J Hematol Blood Transfus 2012;28:123-6.

3 Ganzel C, Constantin R. Parvovirus B19 diagnosed by bone marrow biopsy. Blood 2015;125:3351. 
Images in...

Copyright 2019 BMJ Publishing Group. All rights reserved. For permission to reuse any of this content visit https://www.bmj.com/company/products-services/rights-and-licensing/permissions/

BMJ Case Report Fellows may re-use this article for personal use and teaching without any further permission.

Become a Fellow of BMJ Case Reports today and you can:

- Submit as many cases as you like

- Enjoy fast sympathetic peer review and rapid publication of accepted articles

Access all the published articles

- Re-use any of the published material for personal use and teaching without further permission

For information on Institutional Fellowships contact consortiasales@bmjgroup.com

Visit casereports.bmj.com for more articles like this and to become a Fellow 